\title{
THE IMPACT OF ECONOMIC CRISIS AND NON-ECONOMIC FACTORS ON THE TOURISM INDUSTRY IN ZLATIBOR
}

\section{Slobodan Čerović, , Miroslav Knežević, Nataša Sekulović, Dragoljub Barjaktarović, Filip Đoković}

Singidunum University, Faculty of Tourism and Hospitality Management

32 Danijelova Street, Belgrade, Serbia

\begin{abstract}
:
Tourism has recorded a favorable development trend in the previous decades. Despite the fact that it was occassionaly exposed to adverse effects of the crises caused by numerous economic and non-economic factors, tourism has managed to recover significantly faster and record a higher growth rate compared to the entire world economy. This paper analyses the effects of the economic crisis and other non-economic factors on tourist movements in Serbia during the period 2007-2014, with special emphasis on Zlatibor as a popular tourism destination. The aim of this paper is to show that the aforementioned crisis had a major impact on the movements of domestic and foreign tourists in Serbia and Zlatibor during the analyzed period. Based on the available data, research was conducted and the results showed that the economic factors primarily led to the reduction in the number of tourists in Serbia, while the economic crisis had more impact on domestic travel than on the movements of foreign tourists in our country.
\end{abstract}

\section{INTRODUCTION}

The term 'crisis' is widely used in popular discussions related to economic, social and political issues (Hill, 2014). A crisis represents an important event with possible adverse effects on companies, organizations or industries, and it can also have an impact on their target audience, products, services or reputation (Ketlin Fern-Benks, 2011; Gul et al., 2014; EugenioMartin \& Campos-Soria, 2014). Some authors have defined a crisis as an event of small probability and with serious consequences that can endanger the work of an organization, and it is characterized by vague causes, effects and means of solving it, as well as the conviction that the decisions have to be reached fast (Jaques, 2010; Ghaderi et al., 2014). A crisis can also be defined as an event that is unpleasant and challenging for the decision-makers regarding the movements made under the conditions of high risk, lack of time and insufficient promptness (Boin et al., 2008).

\section{Key words:}

tourist movements,

crisis,

tourism,

Serbia,

Zlatibor.
A crisis can be defined as an undesirable situation that is not typical for the organization/company and is calling for a direct entrepreneurial response due to the seriousness of the event, i.e. as a situation with possible consequences on long-term trust in the organization or product (service) or impeding its normal work (Popesku, 2011).

Despite the absence of a universally accepted definition, it is possible to conclude that the following elements are present with the outbreak of crisis: the key event causing significant changes or potentially being able to cause a significant change, perceived incompetence to deal with the change and threats to organization's future survival (Henderson, 2007; Paraskevas \& Altinay, 2013).

The development of tourism has diverse, and contradictory economic (Zhong \& Hara, 2014; Paraskevas et al., 2013) and non-economic (social, political, cultural) effects (Dehoome et al., 2014; García-Cabrera \& DuránHerrera, 2014; UNWTO, 2015). This paper analyses the 
impact of economic crisis and other non-economic factors on the movements of domestic and foreign tourist demands in Serbia for the period 2007-2014.

\section{SYMPTOMS OF THE ECONOMIC CRISIS IN SERBIA}

During the period from 2007 to this day, the impact of several crises could be felt in Serbia, such as the global economic crisis (Cohen, 2012), AH1N1 virus pandemic (Hanfling \& Altevogt, 2012), political crises (Kosovo independence proclamation), natural disasters (floods and landslidings). These crises have been followed by change in macroeconomic indicators in Serbia (Veselinović, 2012), which directly and indirectly affected the tourist movements in our country during the observed period. The following graph shows the annual growth rates of the GDP for fixed prices in our country for the period 2007-2013.

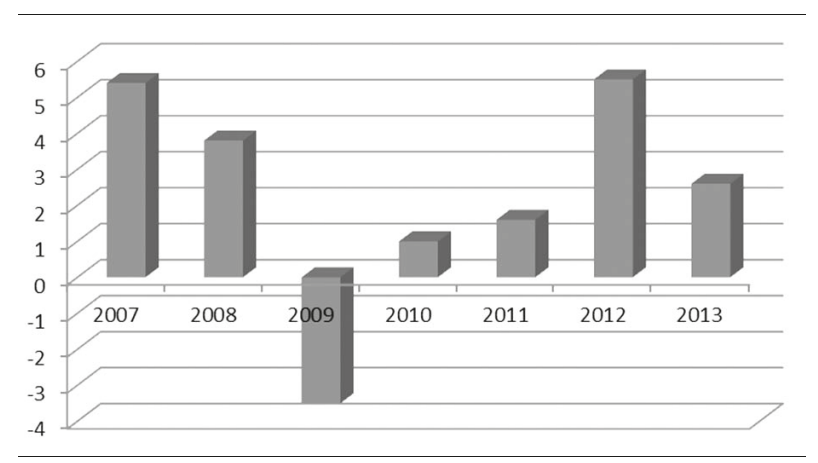

Graph 1. Annual increase of GDP in Serbia for the period 2007-2013 (shown in \%)

Source: Author's research (based on the data from the Statistical Office of the Republic of Serbia)

GDP is not designed to measure social or economic welfare, but is commonly used as an indicator of a country's overall performance (Kubiszewski et al., 2013; Boumans, 2014). A fall in GDP was observed in 2008 compared to 2007 , followed by a radical fall in 2009 under the impact of the global economic crisis (Veselinović \& Makojević, 2012), with the growth rate amounting to $-3.5 \%$ compared to 2008 . Afterwards, the low growth rates continued for a two-year-period and the GDP increased for 5.5\% in 2012. The expectations ensued that this growth would continue in 2013 , but due to the internal economic crisis, the growth rate for the following year decreased to only $2.6 \%$ (Statistical Office of the Republic of Serbia, 2014). We can note that the direct contribution of tourism industry to the gross domestic product (GDP) of Serbia in 2013 was 1.9\% (Jovanović \& Vukasović, 2014).
Personal expenditure is also a very important indicator of a country's economy (Stiglitz et al., 2009). It represents a part of the overall expenditure by which each individual member of the population satisfies his/her needs. (Barać \& Stakić, 2007; Paunović \& Pešić-Andrijić, 2014). As regards personal expenditure in Serbia, a drastic fall can be observed in 2009 compared to 2007 and 2008, due to the ensuing economic crisis. A slight rise occured in 2010 and 2011, which was followed again by a decrease in personal expenditure in 2012.

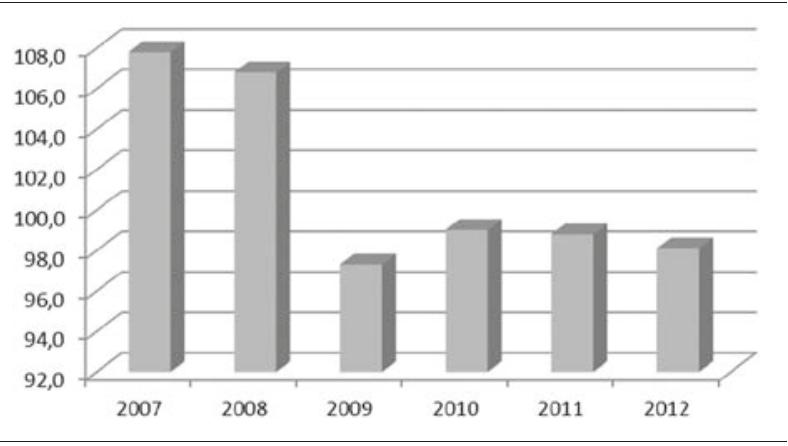

Graph 2. Indices of presonal expenditure growth in Serbia for the period 2007-2012 (shown in \%) Source: Author's research (based on the data from the Statistical Office of the Republic of Serbia)

When we analyse the changes in the number of employees for the analyzed period, a continued decrease in the number of employees can be observed from 2007 till today (Simić, 2011). The number of employees in 2007 amounted to 2,002,344, while it decreased to 1,697,698 in 2014 (the number of employees decreased by $15.1 \%$ compared to 2007 ).

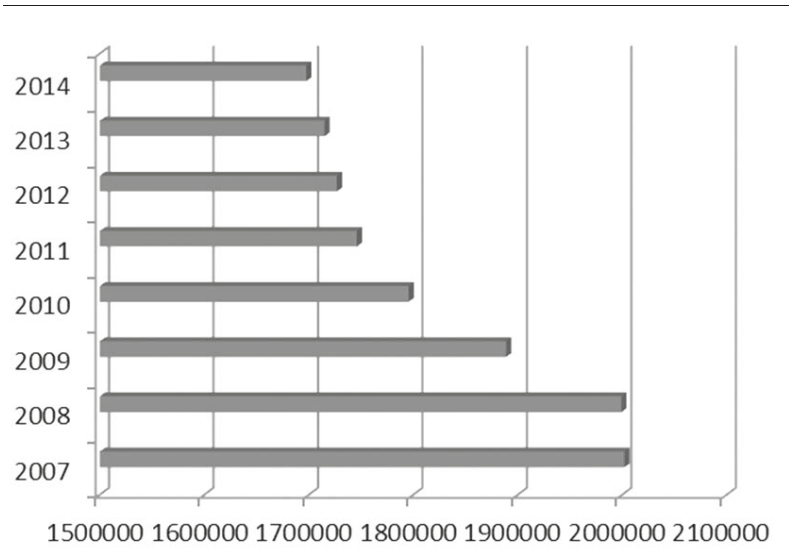

Graph 3. The number of employees in Serbia for the period 2007-2013

Source: Author's research (based on the data from the Statistical Office of the Republic of Serbia) 
The next graph shows the change of average salaries in Serbia (gross and net amount) for the observed period. A slight increase in the average income can be noticed, but we have to point out that it is followed by inflation and unadjusted to the alterations in foreign currency exchange rates (in January 2007, 1 euro could be exchanged for 80 dinars, and in January 2014 for 116 dinars (NBS, 2014).

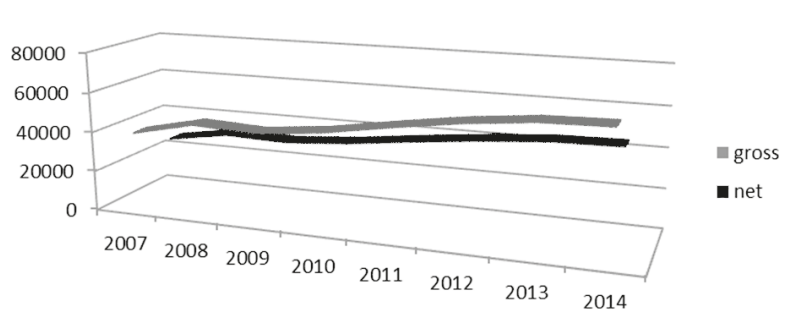

Graph 4. Changes of income in Serbia for the period 2007-2013

Source: Author's research (based on the data from the Statistical Office of the Republic of Serbia)

The following part of the paper shall be devoted to the analysis of the crises and the effects of the aforementioned changes on tourist movement in Serbia, with special emphasis on Zlatibor region.

\section{TOURIST FLOW REALIZED IN SERBIA}

In 2013, the Republic of Serbia realized tourist flow of 2,192,435 tourists, which represents an increase of $5.14 \%$ than in the same period of the previous year. Out of the total number of tourists, 1,270,667 were domestic (58\%), and 921,768 foreign tourists (42\%) (Statistical Office of the Republic of Serbia, 2014). Thus, it is necessary to highlight that there was a greater increase in the number of foreign guests (12\%) compared to domestic ones, which is best supported by the overall economic situation in the country.

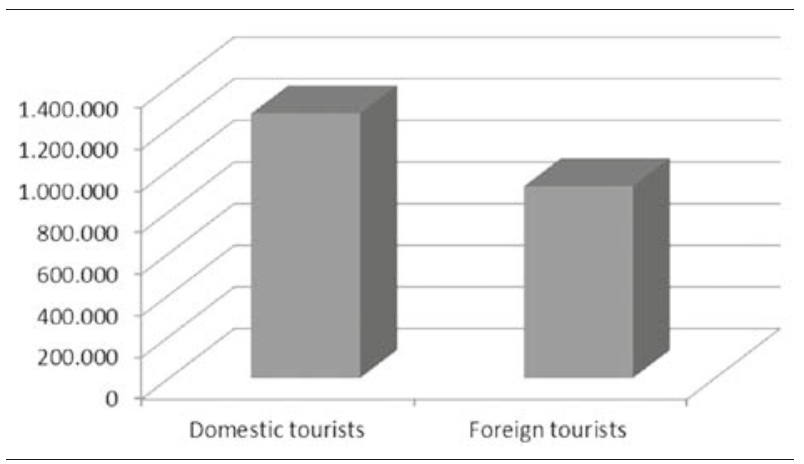

Graph 5. The structure of tourist flow in Serbia for the year 2013.

Source: Author's research (based on the data from the Statistical Office of the Republic of Serbia)

The total of $6,567,460$ overnight stays ( 3 nights per visitor) was realized, of which domestic tourists stayed for 4,579,067 (3.6), and foreign for 1,988,393 (2.16) nights. The number of overnight stays also recorded an increase of $1 \%$ compared to the same period of the previous year. The number of overnight stays by domestic guests recorded a fall of $2 \%$, while the number of overnight stays by foreign guests recorded a rise of $10 \%$. Although the increase in the total number of overnight stays by guests (foreign as well) was recorded, the average number of overnight stays remained almost unaltered.

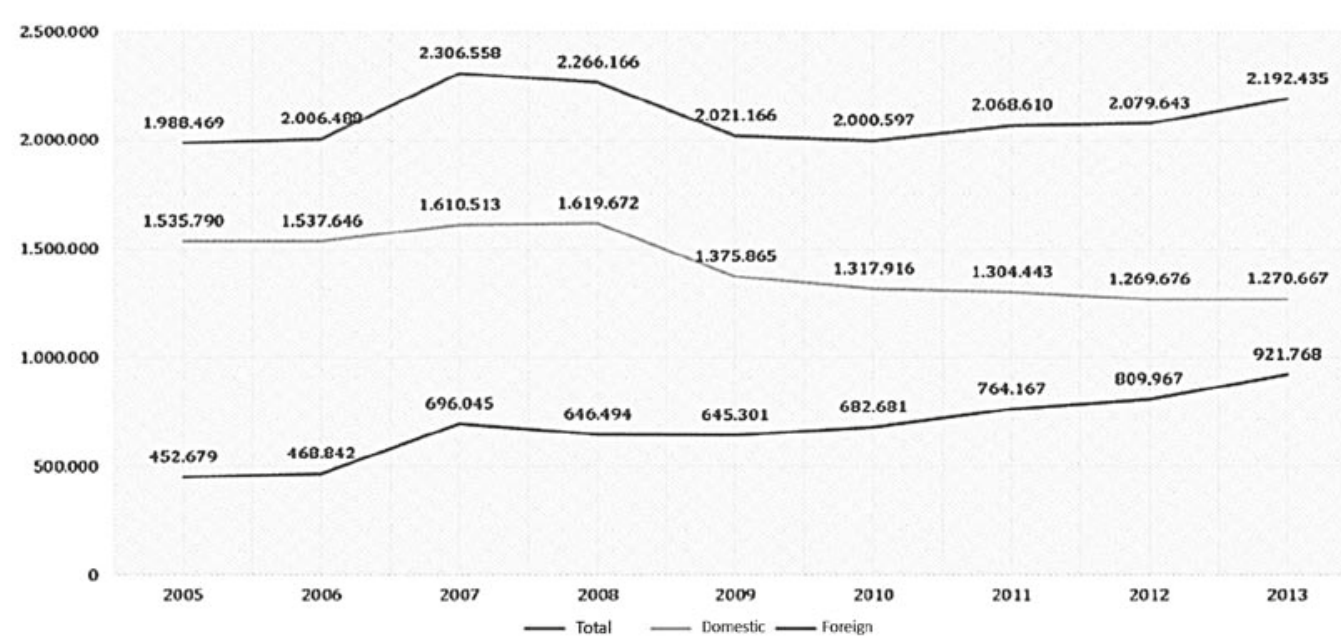

Graph 6. Tourist flow realized in Serbia for the period 2005-2013

Source: Author's research (based on the data from the Statistical Office of the Republic of Serbia) 
As can be observed from the Graph 6, an increase was recorded in the total number of tourists in Serbia for the year 2007. However, due mostly to the impact of the economic crisis in 2008 and 2009, it came to a dramatic decrease (a decrease of $2 \%$ was recorded in 2008 , and a decrease of $13 \%$ in 2009 , compared to 2007). This trend continued in 2010 when a fall of $1 \%$ was recorded compared to the previous year and a fall of $14 \%$ compared to 2007 . In 2011, a slight rise was observed and this tendency continued during 2012 and 2013. However, the results for the year 2013 were worse than in 2008 (3.3\% less visits) and 2007 (5\% less tourist visits). It has to be stressed that during the analyzed period, the decrease was primarily observed in the number of domestic tourist visits, while the number of foreign visits to our country increased during the period 2009-2013. The growth rates of foreign tourists were low, but the number of foreigners in 2013 increased for $32 \%$ compared to 2007. This leads to the conclusion that the crisis had greater impact on domestic than on foreign tourist movements in our country. Therefore, the following part of this paper shall be devoted to the analysis of tourist movements in Serbia during the observed period.

For the purpose of this paper, the tourist destination of Zlatibor has been chosen, as a sample representing the movement of domestic and foreign demand during the period marked by the great economic crisis, pandemic of AH1N1 influenza, internal political crisis (proclamation of Kosovo independence) and the introduction of visa liberalization. The main reasons for choosing Zlatibor include its role in Serbian tourism (it was the fourth most visited destination in Serbia in 2013, following Belgrade, Vrnjacka Banja and Novi Sad (SORS, 2014)), and its guest structure dominated by domestic visitors ( $90 \%$ of total traffic).

\section{RESULTS ACHIEVED IN TOURISM BUSINESS OF ZLATIBOR}

According to the tourism development strategy, the Republic of Serbia has defined the foundations for the development of tourism till 2015. In the part of this strategy named "Competitiveness Plan", the region of Zlatibor is, as a unique tourist destination, mentioned as "a mountainous summer-winter resort in a cluster of established steps of optimal development model for the segment of mountain vacations" (Šuljagić, 2010; Paunović, 2013). Zlatibor is also known as one of the most popular conference destinations and is one of the most developed tourist areas of the Southwestern Serbia cluster (Šušić \& Mojić, 2014; Bošković \& Milenković, 2012).

In 2013, Zlatibor recorded the tourist flow of 114,976 tourists, which represents an increase of $3.6 \%$ compared to the same period of the previous year. Among those, 93,858 were domestic tourists (82\%), and 21,118 foreign tourists (18\%). According to these data, Zlatibor participates in the total tourist flow in Serbia with $5.24 \%$, with the participation in domestic and foreign traffic being $7.39 \%$ and $2.29 \%$, respectively.

An overall of 455,759 nights were realized (3.96 nights per a visitor), of which domestic tourists realized 388,344 (4.16), and foreign 67,415 (3.19 nights). Although the number of visits recorded an increase of $3.6 \%$, the number of overnight stays recorded a decrease of $1.6 \%$ compared to the previous year. As regards the total number of tourists in Serbia, Zlatibor's share is $6.96 \%$, i.e. $8.48 \%$ in the total number of overnight stays by domestic tourists and $3.39 \%$ by foreign tourists.

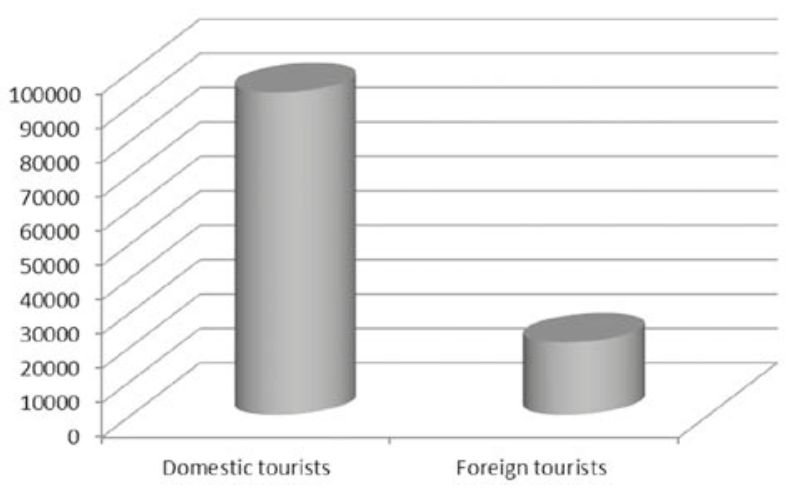

Graph 7. The structure of tourist flow in Zlatibor for the year 2013.

Source: Author's research (based on the data from the Statistical Office of the Republic of Serbia)

The next graph clearly shows that for the first nine months in 2014 Zlatibor assumed the leading position in the number of visits and overnight stays compared to other mountain areas in Serbia, which classifies it, together with Kopaonik, among the most attractive mountain destinations in this region.

As we have already pointed out, the tourist destination of Zlatibor belongs to the group of the leading mountain areas in Serbia, and thus we have analysed the obtained results for the tourist activity of this destination, with the movements of domestic and foreign tourist demand being shown in continuation. 


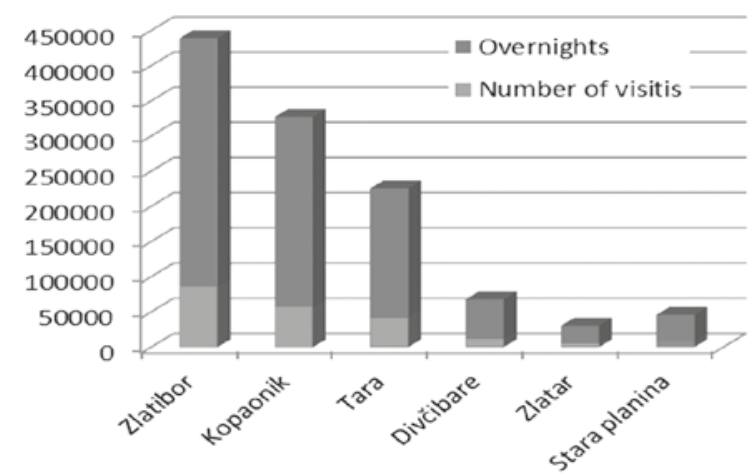

Graph 8. The list of mountain destinations and number of visits, January 2014

Source: Author's research (based on the data from the Statistical Office of the Republic of Serbia)

We have used the chronological series, to show the arrivals and overnight stays by domestic and foreign tourists for the period 2007-2013.
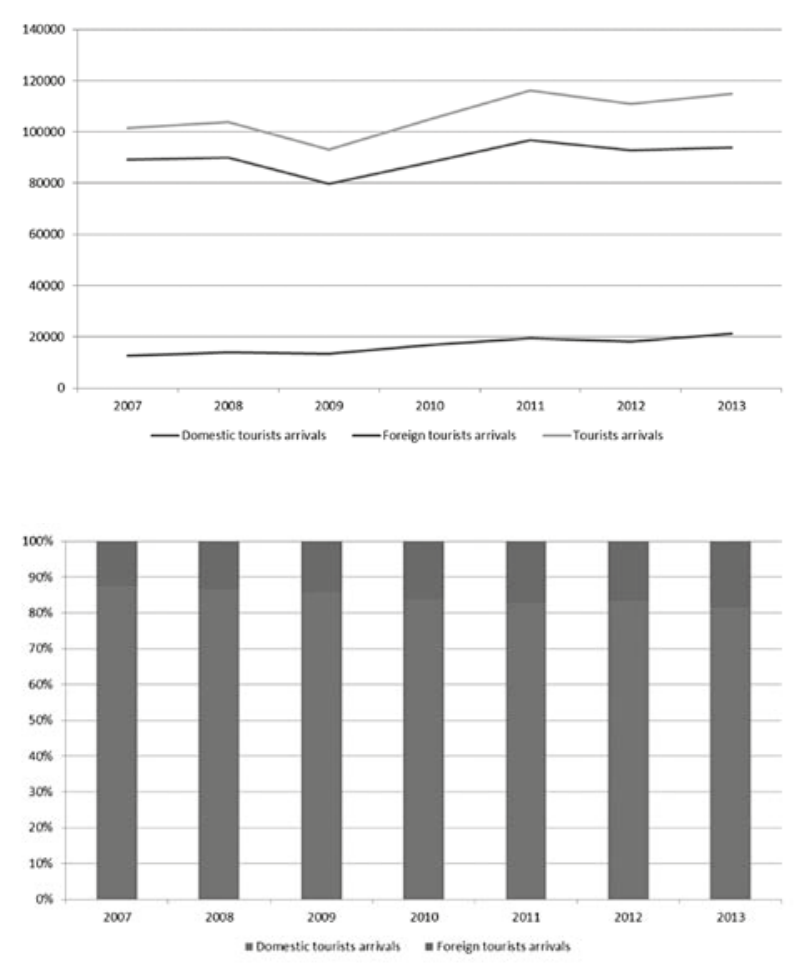

Graph 9 and 10. The arrivals of domestic and foreign tourists (total) for the period 2007-2013

Source: Author's research (based on the data from the Statistical Office of the Republic of Serbia)

Tourist flow measured by the number of tourist visits has positive dynamics for the period 2007-2008, while a drastic fall was observed in 2009.

The reasons for a decrease in the overall tourist flow in 2009 were numerous, but we consider that the most significant are the global economic crisis and the pandemic of AH1N1 virus. The media in the surrounding countries presented Zlatibor as an infected area and addressed recommendation to potential visitors not to travel to this destination, as a preventive, although this was far from truth, which resulted in a lower number of tourists from these countries. In addition, as one of the factors causing the drop in tourist flow, we would like to highlight the signing of the agreement on visa liberalization, which enabled our citizens to travel to "the Schengen countries" without visas. Tourist agencies utilized this and offered lowcost trips abroad. The designers of Zlatibor tourism policy did not react appropriately and the drop of $10 \%$ was unavoidable.

After the decrease in the total number of tourist visits to Zlatibor in 2009, an increase of $12.6 \%$ could be observed during 2010 compared to the previous year. This is one additional symptom that the tourism in the area of Zlatibor "recovered" much quicker from the consequences of the crisis and influenza pandemic in relation to other industries (and in relation to movements on the national level).

The positive tendency continued in 2011 with the increase of $10.9 \%$ compared to the previous year. According to the expert forecasts, this tendency was supposed to continue in 2012 and 2013, but those assumptions proved to be wrong. We deem that the causes for this were the significant economic issues that became prominent in the Republic of Serbia, due to the fact that the main body of tourists in Zlatibor includes mainly domestic tourists. We believe that the internal economic crisis primarily led to a decerease of about 5.5\% in the tourist flow in Zlatibor in 2012 compared to the previous year.

The following graphs show the movement and structure of tourists in the overall tourist flow for the period 2007-2013. 


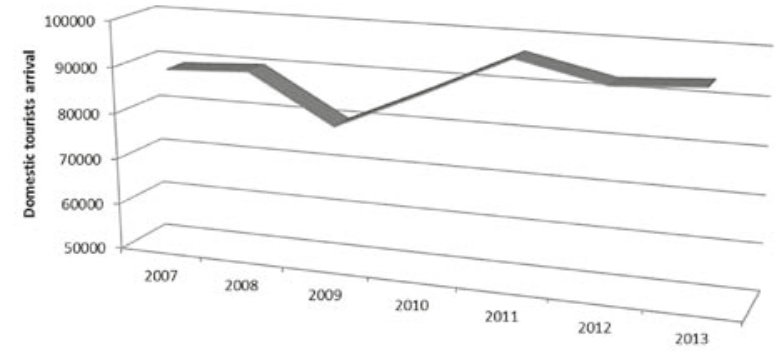

Graph 11. Visits by domestic tourists 2007-2013

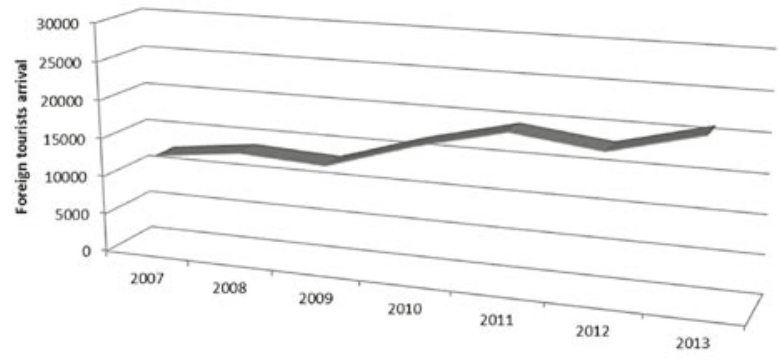

Graph 12. Visits by foreign tourists 2007-2013

Source: Author's research (based on the data from the Statistical Office of the Republic of Serbia)

It could be observed that the structure is dominated by domestic tourists and that their number has diminished drastically for the previously analyzed period (2009-2010 and 2012-2013). On the other hand, the number of foreign tourists in 2013 increased for almost $70 \%$ compared to 2007 . Moreover, the participation of foreign tourists in the total number of visits is gaining more and more significance (the participation of foreigners in the overall traffic was $12.29 \%$ in 2007 and $18.38 \%$ in 2013).

The fluctuations also occur in the number of overnight stays made by tourists for the observed period (Graphs 13 and 14). The lowest number of overnight stays was recorded in $2009(388,987)$, while in 2010 and 2011, an increase was recorded (in 2011 a track of 475,300 nights was kept), while in 2012 and 2013, a conspicuous decrease can be observed (in 2013 455,759 overnight stays were recorded).

For the period of I-IX/2009, the drop in the total number of overnight stays amounted to $14.71 \%$. With the aim of impartial and realistic observation of the movement in tourist flow, the resort "Lovac" was excluded from this analysis as it has been closed since July 1, 2009. If the hotel "Zelenkada", which has been doing business rather badly due to the privatization issues, was excluded as well, then the total drop in tourist flow would be $10.9 \%$.
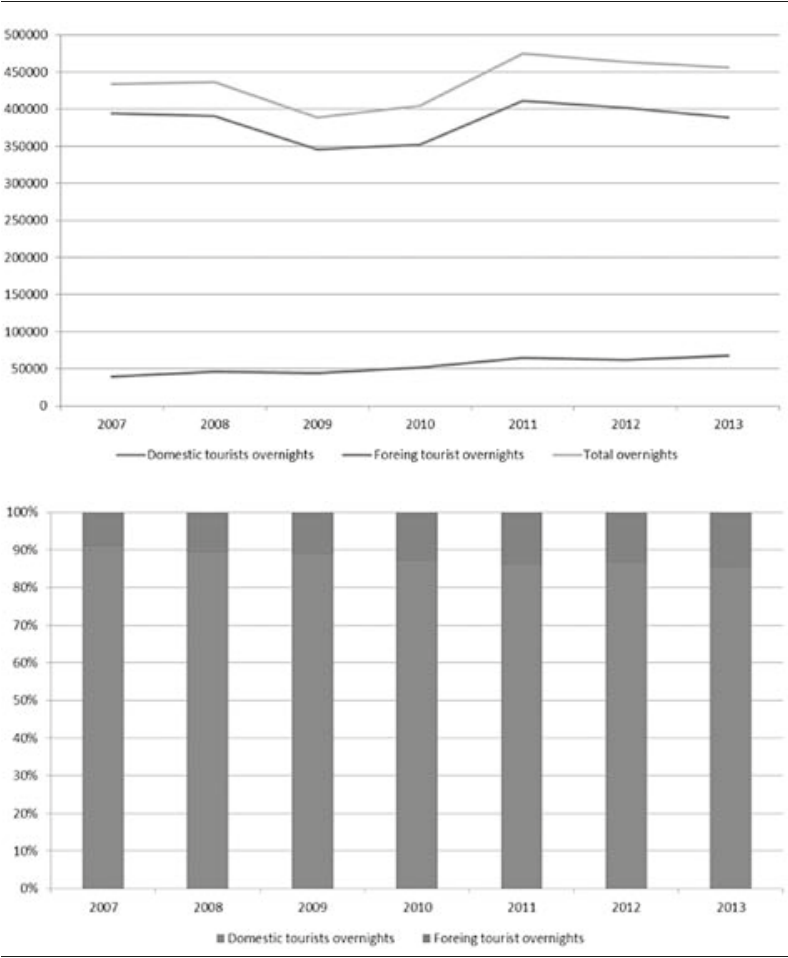

Graphs 13 and 14. Domestic and foreign tourist overnight stays 2007-2013

Source: Author's research (based on the data from the Statistical Office of the Republic of Serbia)

After this drastic decrease in 2009 (the reasons for this have been already presented by analyzing the drop in tourist flow measured by the number of visits), the overall number of overnight stays slightly increased in 2010 and 2011, compared to 2007. This growing trend was expected to continue in 2012 and 2013. However, there came to a new drop in the total number of overnight stays. According to the data from the Statistical Office of the Republic of Serbia, the local tourist organization and our study, domestic tourist demand prevailed in Zlatibor region during the observed period, and this segment of tourists participates with $85 \%-90 \%$ in the total number of overnight stays.

The following graphs show separately the overnight stays made by domestic tourists and foreign tourists for the analyzed period. It is noticeable that the number of overnight stays made by domestic tourists drastically decreased (the number of overnight stays by domestic tourists diminished by $2 \%$ in 2013 compared to 2007), while the number of overnight stays by foreign guests increased (except for 2012 when the number of overnight stays by foreign tourists decreased as well, but to a far lesser degree compared to domestic tourists). In 2013, 70\% more overnight stays were recorded than in 2007. 


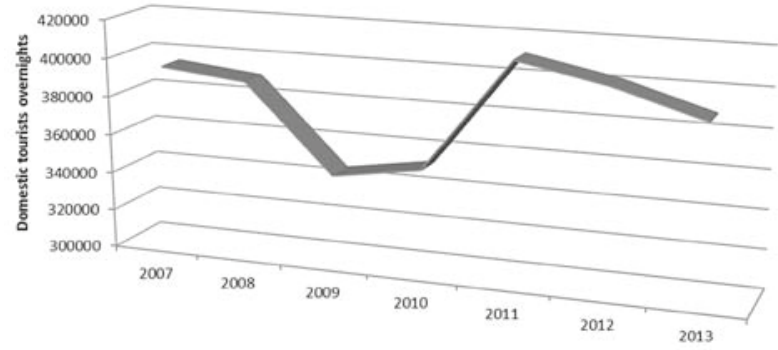

Graph 15. Domestic tourist overnight stays 2007-2013

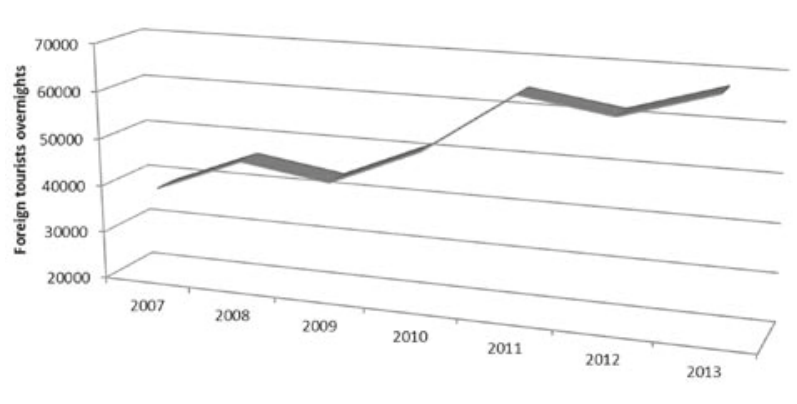

Graph 16. Foreign tourists overnight stays 2007-2013

Source: Author's research (based on the data from the Statistical Office of the Republic of Serbia)

One of the major causes of the decrease in the number of overnight stays by domestic tourists is certainly the internal economic crisis which has been troubling Serbia for the last several years. As we can see, tourists still visit Zlatibor, but their stays are shorter than before (due to the drop in income, the tourists shortened the duration of their stay).

The lowest number of overnight stays is recorded during the nonseasonal months (February, March, October and November). The fluctuations in the number of visits and overnight stays by tourists can be best observed if we take a look at the recorded visits during the seasonal months (June, July, August, and January) and nonseasonal ones. Based on the processed data, we can conclude that the average use of categorized basic accommodation capacities does not exceed $60 \%$ (the most profitable was in 2008, with the use of 59\%), but it could still be observed that the number of accommodation units in basic accommodation capacities recorded a growth during the observed years (2007 - 1,931 beds; 2010 - 2,098 beds; 2014 - 2,914 beds). One of the reasons for this below - average booking of basic accommodation capacities is certainly unfair competition from complementary accommodation capacities (private villas and apartments), but this will not be examined in this paper. It is certainly encouraging that the number of beds in hotels is growing and it would be good for this tendency to continue in future.

Moreover, during the analysis and classification of these data, we have to mention that a special problem comprises tourist flow in private accommodation, since there is a vast number of unregistered guests and it is impossible to ascertain the exact information on the number of tourists and their overnight stays.

The problem of inadequate capacity of accommodation and traffic is familiar from before and it has several aspects. The first one includes those proprietors who avoid to register their guests (or they let apartments and rooms without the authorities' approval), i.e. those capacities are not registered as accommodation units with the tourist flow and charging of tax on stays. The second one is connected to visits to friends and relatives - this segment is also not reported nor registered. The third encompasses all those individuals staying at their own apartments or holiday houses who are not registered nor consider themselves tourists.

\section{CONCLUSION}

The great economic crisis that broke out at the end of 2008, and continued till today, has had a negative impact on the tourism industry in our country. Such negative influence reflected on the results of Zlatibor tourism, as one of the most visited destinations in Serbia. The impact of economic factors on tourist flow and expenditure in Serbia is more prominent compared to the influence of non-economic factors. Based on the research results, it is evident that tourism was severely affected by the economic crisis in 2009, when a more dramatic decrease in the realized tourist flow and overnight stays was recorded. Afterwards, in 2010 the tourism already showed the signs of recovery, which continued more seriously in 2011 and 2012. However, a new drop occured in 2012, which was caused primarily by the internal economic crisis. By analyzing the observed period, we reached a conclusion that the economic crisis and other non-economic factors have more significantly influenced the movement of domestic tourist demand compared to the foreign one. In 2013, the tourism once more showed resilience and the ability to recover faster compared to the movements in the national economy and other economic sectors. This is the very confirmation that tourism, in this period, as well as in the case of all previous crises, managed to recovered significantly faster in relation to the overall economy. 


\section{REFERENCES}

Barać, S., \& Stakić, B. (2007). Osnovi ekonomije. Beograd: Univerzitet Singidunum. (In Serbian)

Boin, A., McConnell, A., \& 't Hart, P. (2008). Governing after Crisis: The politics of Investigation, Accountability and Learning. Cambridge: Cambridge University Press.

Coyle, D. (2014). GDP: A Brief but Affectionate History. Princeton: Princeton University Press.

Bošković, N., \& Milenković, S. (2012). Razvojne tendencije ekoturizma Srbije. Teme: Časopis za drušvenu teoriju $i$ praksu. 2, 483-499. (In Serbian)

Cohen, E. (2012). Globalization, global crises and tourism. Tourism recreation research. 37(2), 103-111.

Dehoorne, O., Depault, K., Ma, S.Q., \& Cao, H.H. (2014). International Tourism: Geopolitical Dimensions of a Global Phenomenon. In B.-Y. Cao et al. (Ed.) Ecosystem Assessment and Fuzzy Systems Management (pp. 389-396). Springer International Publishing. DOI: 10.1007/978-3-319-03449-2_35

Eugenio-Martin, J. L., \& Campos-Soria, J. A. (2014). Economic crisis and tourism expenditure cutback decision. Annals of Tourism Research. 44, 53-73. DOI: 10.1016/j.annals.2013.08.013

Fern-Benks, K. (2011). Crisis communications: A casebook approach. New York: Taylor \& Francis.

García-Cabrera, A. M., \& Durán-Herrera, J. J. (2014). Does the tourism industry co-evolve? Annals of Tourism Research. 47, 81-83. DOI:10.1016/j.annals.2014.05.004

Ghaderi, Z., Mat Som, A.P., \& Wang, J. (2014). Organizational Learning in Tourism Crisis Management: An Experience from Malaysia. Journal of Travel \& Tourism Marketing. 31(5), 627-648. DOI: 10.1080/10548408.2014.883951

Gul, K., Asik, N.A., \& Gurbuz, A.K. (2014). The Effect of Global Economic Crisis on Turkish Tourism Demand and a Review for the Period 2003-2013. Journal of World Economic Research. 3(6-1), 22-32. DOI: 10.11648/j.jwer.s.2014030601.14

Hanfling, D., \& Altevogt, B.M. (2012). A Framework for Catastrophic Disaster Response. JAMA. 308(7), 675681. DOI: 10.1001/jama.2012.8171

Henderson, J. (2007). Tourism crisis: Causes, consequences and management. Oxford: Elsavier.

Hill, M. (2014). Reflections on the politics of the economic crisis from a policy process perspective. Anali Hrvatskog politološkog društva. 10(1), 41-56.

Jaques, T. (2010). Reshaping crisis management: The challenge for organizational design. Organization Development Journal. 28(1), 9-17.

Jovanović, V., \& Vukasović, S. (2014). Adapting the TSA to measure economic contribution of tourism in Ser- bia. Singidunum Journal of Applied Sciences. 11(2), 1-10. DOI: $10.5937 /$ sjas11-4463

Kubiszewski, I., Costanza, R., Franco, C., Lawn, P., Talberth, J., Jackson, T., \& Aylmer, C. (2013). Beyond GDP: Measuring and achieving global genuine progress. Ecological Economics. 93, 57-68. DOI:10.1016/j. ecolecon.2013.04.019

Najdić, M., \& Sekulović, N. (2012). Behavior of Serbian Tourists during Economic Crisis: Two Empirical Researches. Turizam. 16(4), 180-192.

Paraskevas, A., \& Altinay, L. (2013). Signal detection as the first line of defence in tourism crisis management. Tourism Management. 34, 158-171. DOI:10.1016/j.tourman.2012.04.007

Paraskevas, A., Altinay, L., McLean, J., \& Cooper, C. (2013). Crisis knowledge in tourism: Types, flows and governance. Annals of Tourism Research. 41, 130-152. DOI:10.1016/j.annals.2012.12.005

Paunović, I. (2013). Proposal for Serbian Tourism Destinations Marketing Campaign. Singidunum Journal of Applied Sciences. 10(2), 40-52. DOI: 10.5937/sjas10-4327

Paunović, S., \& Pešić-Andrijić, M. (2014). Ekonomoketrijski model lične potrošnje. Zbornik radova Ekonomskog fakulteta u Istočnom Sarajevu, (8), 99-105. DOI: 10.7251/ZREFIS1408247P (In Serbian)

Pearson, C. \& Clair, J. (1998). Reframing Crisis Management. The Academy of Management Review. 23(1), 59-76.

Popesku, J. (2011). Menadžment turističke destinacije. Beograd: Univerzitet Singidunum. (In Serbian)

Ritchie, B.W., Crotts, J.C., Zehrer, A., \& Volsky, G.T. (2013). Understanding the effects of a tourism crisis: the impact of the BP oil spill on regional lodging demand. Journal of Travel Research. 1, 2013. DOI: 10.1177/0047287513482775

Sekulović, N. (2011). The Impact of the Global Economic Crisis on the Attitudes of the Citizens of Serbia towards Leisure Travel. Singidunum revija, 8(2), 111-118.

Simić, V. (2011). Uticaj ekonomske krize na socijalnu politiku Srbije u periodu 2008-2011. Godišnjak br. 06, 507-520. (In Serbian)

Stiglitz, J., Sen, A., \& Fitoussi, J.P. (2009). The measurement of economic performance and social progress revisited. Reflections and overview. Commission on the Measurement of Economic Performance and Social Progress, Paris.

Statistical Office of the Republic of Serbia. (2015). Tourism. Retrieved March 25, 2015, from http://webrzs.stat.gov. rs/WebSite/Public/PageView.aspx?pKey=180

Unković, S., \& Sekulović, N. (2010). Mere za ublažavanje negativnog dejstva svetske ekonomske krize na turizam. Singidunum revija. 7(2), 181-192. (In Serbian)

Unković, S., \& Zečević, B. (2014). Ekonomika turizma. Beograd: Ekonomski fakultet. (In Serbian) 
UNWTO. (2015). World Tourism Barometer and Statistical Annex. Retrieved March 25, 2015, from http://www. eunwto.org/content/1407r60414k52204/fulltext? $\mathrm{p}=2 \mathrm{e}$ 4f3e5750404d39ab05e15641 ce8756\&pi $=0 \#$ section $=11$ 90844 \&page $=2 \&$ locus $=0$

Veselinović, P. (2012). Izazovi ekonomske nauke u uslovima globalne ekonomske krize. Ekonomske teme. 2012(4), 433-450. (In Serbian)

Veselinović, P., \& Makojević, N. (2012). Komparativna analiza makroekonomskih pokazatelja Srbije, Bugarske i Rumunije u procesu tranzicije. U: Institucionalne promene kao determinanta privrednog razvoja Srbije, 135-155. Kragujevac: Ekonomski fakultet. DOI: 451-03-00580/2012-14 (In Serbian)
Zhong, Y.Y., \& Hara, T. (2014). Quantifying the Impacts of the Recent Economic Crisis on a Regional Tourism Industry and Economy. Hospitality Review. 31(1), 10.

Šušić, V., \& Mojić, J. (2014). Kongresni turizam kao tržišna niša poslovnog turizma. Ekonomske teme. 2014(4), 523539. (In Serbian)

Šuljagić, S. (2010). Doprinos turizma razvoju regiona Zlatibor. Politička revija. 9(1), 249-271. (In Serbian)

\section{UTICAJ EKONOMSKE KRIZE I NEEKONOMSKIH FAKTORA NA TURIZAM NA ZLATIBORU}

\section{Rezime:}

Turizam beleži pozitivan trend razvoja tokom prethodnih decenija. Uprkos činjenici da je povremeno bio pogođen krizom prouzrokovanom brojnim ekonomskim i neekonomskim činiocima, uspeo je da se brže oporavi i beleži veću stopu rasta u odnosu na ostale segmente privrede. Ovaj rad ispituje uticaj ekonomske krize i drugih neekonomskih činilaca na razvoj turizma u Srbiji tokom perioda 2007-2014, sa posebnim naglaskom na Zlatibor kao jednu od popularnih turističkih destinacija. Cilj ovog rada jeste da pokaže da je pomenuta kriza imala ogroman uticaj na kretanja domaćih i stranih turista u Srbiji i na Zlatiboru tokom navedenog perioda. Na osnovu dostupnih podataka, sprovedeno je istraživanje čiji su rezultati pokazali da su ekonomski faktori doveli do pada u broju turista u Srbiji, kao i da je ekonomska kriza imala veći uticaj na kretanja domaćih turista nego na kretanja stranih turista u zemlji.

\section{Ključne reči:}

kretanje turista,

kriza,

turizam,

Srbija,

Zlatibor

Received: March 10, 2015.

Correction: March 15, 2015.

Accepted: April 2, 2015. 